\title{
Palmar Intertriradial Ridge Counts in Sardinians
}

\author{
Giovanni Floris \\ University of Cagliari, Cagliari, Italy \\ Email: giofloris@alice.it
}

Received 4 May 2015; accepted 7 August 2015; published 10 August 2015

Copyright (C) 2015 by author and Scientific Research Publishing Inc.

This work is licensed under the Creative Commons Attribution International License (CC BY). http://creativecommons.org/licenses/by/4.0/

\section{(c) (i) Open Access}

\begin{abstract}
Palmar intertriradial ridge counts (a-b, b-c, c-d, a-d) in 260 males and 260 females of Sardinian origin were considered. Bilateral and sex differences, correlation coefficients, skewness and kurtosis of the four distributions and an index of asymmetry were calculated. There are no sex differences, ridge counts show positive and almost always significant correlations. The a-d ridge count shows a normal distribution in both sexes.
\end{abstract}

\section{Keywords}

a-b, b-c, c-d, a-d Ridge Counts, Sardinians

\section{Introduction}

While there are many data about a-b ridge count (Floris and Sanna, 1982; Jantz and Webb, 1982; Pons, 1982), other palmar intertriradial ridge counts are relatively few (Jaeger, 1971; Knussmann, 1971; Hitzeroth and Brehme, 1974; Maté, 1975; Brehme et al., 1977; Dennis, 1977; Reichmann, 1978; Brehme and Hitzeroth, 1979, 1980; Galaktionov et al., 1981; Gill et al., 1982; Babu, 1983; Gyenis, 1984; Karmakar and Malhotra, 1985; Hitzeroth et al., 1986; Jantz et al., 1988-1992; Brehme and Jantz, 1990; Arrieta et al., 1992; Demarchi and Marcellino, 1994-1995; Milicic and Rudan, 1991; Milicic and Vidovic, 2005; Reichmann, 1978; Deep Kumar and Ramachandraiah, 1991; Kamali, 1982; Reddy et al., 2004; Karmakar et al., 1996). The a-d ridge count in particular has been examined only in Asiatic populations (Basu, 1971; Chattopadhyay and Kushwaka, 1978; Balgir and Sharma, 1986; Narahari et al., 2008; Bhasin, 1970; Bansal et al., 1984; Chai, 1971), and in Sardinians (Floris, 1993; Floris and Sanciu, 1989), while data on persons from Bologna (Gualdi-Russo, 1987) from Galicia (Lodeiro Ainsua et al., 1985) and from Bulgaria (Tornjava-Randelova et al., 2008) were given by the sum of a-b, b-c and c-d counts and not directly by calculating the ridges crossing, or which in any case touching, the line joining triradii a and d (Cummins and Midlo, 1961). Ahuja et al., 1977, measured the distance a-d in centimetres. Hauser and Abraham (1985) only measured the b-c and c-d ridge counts. One of the difficulties met with in cal- 
culating intertriradial ridge counts is the not infrequent absence of triradius c (triradius d, which is also sometimes absent, is so with a frequency of only $0.06 \%$ of Sardinians of both sexes, Floris and Sanna, 1983), which for example shows up in $2.94 \%$ of Sardinian males (Floris and Sanna, 1987). To make up for this absence, it is possible either not to consider prints without triradius c (Rosa, 1983) or estimate its presumed position (Braitsch and Scwarzfischer, 1959). In this note, we adopt the first method because having examined a small sample of individuals belonging to the same group of prints in which the intertriradial counts were calculated where triradius c was absent in one (or both) palms and made up of 12 males and 12 females (Floris and Sanciu, 1989) significantly differing average values (in the two sexes as well as in the two sides) were obtained, with the exception of the a-b ridge count, with respect to values obtained in the sample with triradius $\mathrm{c}$ always present. For this reason, it was decided to examine only, at least in this note, the prints with triradius c present and not estimated. One can not neglect at last the critical remarks of Weninger (1978) about b-c and c-d ridge counts and the probability that some results are incorrect, because the ridges cross the b-c or c-d line can be more or less obliques and not at nearly right angles (as for the a-b ridge count or for the determination of the finger ridge count).

For all the reasons mentioned above, it can therefore be considered useful to increase our knowledge concerning palmar intertriradial ridge counts in a sample belonging to the Europoid population.

\section{Materials and Methods}

The data reported concern the four palmar intertriradial ridge counts (a-b, b-c, c-d, a-d) in 260 Sardinian males and 260 Sardinian females, chosen from the different palm prints on file at our Department, taking into account possible sex and side differences, correlations, the normality of the distributions (skewness and kurtosis) and the asymmetry. Among the various indices that have been advanced to examine bilateral asymmetry, we have chosen for his simplicity and for the reasons brought by the Author, the asymmetry index proposed by Jantz (1975) for digital ridge counts, adapted for four characters:

$$
\text { A.I. }=\sqrt{\sum_{1}^{4}\left(R_{i}-L_{i}\right)^{2}} .
$$

\section{Results and Discussion}

Table 1 gives the means and standard deviations and the result of the analysis of differences of sex (Student's

Table 1. The intertriradial palmar ridge counts (mean and standard deviation of the mean).

\begin{tabular}{|c|c|c|c|c|c|c|c|c|c|}
\hline & & $\mathrm{R}$ & $\mathrm{SD}$ & $\mathrm{L}$ & SD & $\mathrm{R}+\mathrm{L}$ & SD & $\bar{D} / \sigma_{\bar{D}}$ & $\mathrm{t}(\mathrm{R} \times \mathrm{L})$ \\
\hline \multicolumn{10}{|l|}{$a-b$} \\
\hline & M & 40.54 & 5.64 & 41.40 & 5.58 & 81.93 & 10.36 & $3.22^{* *}$ & 1.75 \\
\hline & $\mathrm{F}$ & 40.42 & 5.60 & 41.94 & 6.40 & 82.37 & 11.26 & $5.79^{* *}$ & $2.88^{* *}$ \\
\hline & $\mathrm{t}(\mathrm{M} \times \mathrm{F})$ & 0.23 & & 1.04 & & 0.45 & & & \\
\hline \multicolumn{10}{|l|}{ b-c } \\
\hline & M & 27.22 & 5.79 & 26.79 & 5.55 & 54.01 & 10.78 & $1.98^{*}$ & 0.86 \\
\hline & $\mathrm{F}$ & 28.01 & 5.61 & 27.15 & 6.01 & 55.17 & 11.08 & $3.97^{* *}$ & 1.69 \\
\hline & $\mathrm{t}(\mathrm{M} \times \mathrm{F})$ & 1.58 & & 0.71 & & 1.20 & & & \\
\hline \multicolumn{10}{|l|}{$c-d$} \\
\hline & M & 36.39 & 5.27 & 35.46 & 5.66 & 71.85 & 10.00 & $3.38^{* *}$ & 1.94 \\
\hline & $\mathrm{F}$ & 36.13 & 6.01 & 35.81 & 6.17 & 71.94 & 11.36 & 1.16 & 0.60 \\
\hline & $\mathrm{t}(\mathrm{M} \times \mathrm{F})$ & 0.54 & & 0.67 & & 0.09 & & & \\
\hline \multicolumn{10}{|l|}{$\mathrm{a}-\mathrm{d}$} \\
\hline & M & 82.15 & 15.85 & 83.60 & 16.54 & 165.75 & 31.29 & $2.80^{* *}$ & 1.02 \\
\hline & $\mathrm{F}$ & 84.27 & 16.40 & 84.93 & 16.24 & 169.19 & 31.60 & 1.31 & 0.46 \\
\hline & $\mathrm{t}(\mathrm{M} \times \mathrm{F})$ & 1.50 & & 0.92 & & 1.25 & & & \\
\hline \multicolumn{10}{|l|}{ A.I. } \\
\hline & M & & & & & 10.06 & 4.79 & & \\
\hline & $\mathrm{F}$ & & & & & 9.94 & 4.50 & & \\
\hline & $\mathrm{t}(\mathrm{M} \times \mathrm{F})$ & & & & & 0.29 & & & \\
\hline
\end{tabular}

${ }^{*} p \leq 0.05,{ }^{* *} p \leq 0.01$. 
test) and side (in this case, since the variables under examination are not independent, the paired data test was used, Barbensi, 1952).

As can be seen from Table 1, the values on the right are larger than those on the left in both sexes for counts b-c and c-d, while they are higher on the left for counts a-b and a-d. Values are higher in males than in females only for counts a-b and c-d on the right and higher in females in all other cases.

Side differences are significant for all the counts in males (but they are not if we do not use the test $\mathrm{t}$ for paired data!) and for a-b and b-c counts in females (only for a-b count with $t$ test for non paired data). These differences show that the directional asymmetry (if the bilateral differences are not significant the asymmetry is fluctuating, if they are statistically significant the asymmetry is said directional) is small (about one ridge in favor of the left hand for a-b and a-d ridge counts and in favor of the right hand for b-c and c-d ridge counts) but statistically almost always significant, as seen for a-b ridge count by Jantz and Webb (1982).

Sex differences are in any case never significant.

The correlation coefficients for palmar intertriradial ridge counts are given in Table 2. All correlations are

Table 2. Correlations among the intertriradial palmar ridge counts.

\begin{tabular}{|c|c|c|c|c|c|c|c|c|c|c|c|c|}
\hline \multicolumn{13}{|c|}{ Males } \\
\hline & Ra-b & $\mathrm{Rb}-\mathrm{c}$ & Rc-d & Ra-d & La-b & Lb-c & Lc-d & La-d & RLa-b & RLb-c & RLc-d & RLa-d \\
\hline Ra-b & 1.00 & & & & & & & & & & & \\
\hline Rb-c & 0.30 & 1.00 & & & & & & & & & & \\
\hline Rc-d & 0.11 & 0.18 & 1.00 & & & & & & & & & \\
\hline Ra-d & 0.37 & 0.51 & 0.35 & 1.00 & & & & & & & & \\
\hline La-b & 0.71 & 0.28 & 0.20 & 0.36 & 1.00 & & & & & & & \\
\hline Lb-c & 0.33 & 0,81 & 0.23 & 0.53 & 0.26 & 1.00 & & & & & & \\
\hline Lc-d & 0.23 & 0.36 & 0.67 & 0.51 & 0.25 & 0.29 & 1.00 & & & & & \\
\hline La-d & 0.39 & 0.48 & 0.33 & 0.87 & 0.37 & 0.56 & 0.47 & 1.00 & & & & \\
\hline RLa-b & 0.92 & 0.32 & 0.16 & 0.40 & 0.92 & 0.32 & 0.26 & 0.41 & 1.00 & & & \\
\hline RLb-c & 0.33 & 0.95 & 0.21 & 0.55 & 0.28 & 0.95 & 0.35 & 0.55 & 0.33 & 1.00 & & \\
\hline RLc-d & 0.19 & 0.30 & 0.91 & 0.47 & 0.24 & 0.29 & 0.92 & 0.44 & 0.23 & 0.31 & 1.00 & \\
\hline RLa-d & 0.39 & 0.51 & 0.35 & 0.96 & 0.38 & 0.56 & 0.51 & 0.97 & 0.42 & 0.57 & 0.47 & 1.00 \\
\hline \multicolumn{13}{|c|}{ Females } \\
\hline Ra-b & 1.00 & & & & & & & & & & & \\
\hline Rb-c & 0,29 & 1.00 & & & & & & & & & & \\
\hline Rc-d & 0.29 & 0.07 & 1.00 & & & & & & & & & \\
\hline Ra-d & 0.43 & 0.67 & 0.37 & 1.00 & & & & & & & & \\
\hline La-b & 0.76 & 0.34 & 0.32 & 0.42 & 1.00 & & & & & & & \\
\hline Lb-c & 0.35 & 0.82 & 0.11 & 0.63 & 0.34 & 1.00 & & & & & & \\
\hline Lc-d & 0.31 & 0.27 & 0.74 & 0.46 & 0.33 & 0.19 & 1.00 & & & & & \\
\hline La-d & 0.40 & 0.65 & 0.29 & 0.87 & 0.41 & 0.65 & 0.41 & 1.00 & & & & \\
\hline RLa-b & 0.93 & 0.34 & 0.33 & 0.46 & 0.95 & 0.37 & 0.34 & 0.43 & 1.00 & & & \\
\hline RLb-c & 0.34 & 0.95 & 0.09 & 0.68 & 0.36 & 0.96 & 0.24 & 0.68 & 0.37 & 1.00 & & \\
\hline RLc-d & 0.32 & 0.18 & 0.93 & 0.45 & 0.35 & 0.16 & 0.93 & 0.38 & 0.36 & 0.18 & 1.00 & \\
\hline RLa-d & 0.43 & 0.68 & 0.34 & 0.97 & 0.43 & 0.66 & 0.45 & 0.97 & 0.46 & 0.70 & 0.43 & 1.00 \\
\hline
\end{tabular}

Critical value $(p \leq 0.05)=0.12$. 
positive and in most cases significantly different from zero. The sole exceptions found concern those between a-b and c-d (males on right), between b-c and c-d (females on right) and between c-d (females on right) and b-c (females on left). On the whole correlations are greater in females in the $68 \%$ of the cases, in males in the $27 \%$ and equals in the $5 \%$ of the cases. The existence of sex differences in the correlations may suggest that the sex chromosomes may be involved in the control of dermal ridge development (just as suggested for the fingers by Jantz, 1977).

For homologous counts the greatest correlation is found between a-d counts in both sexes, for non homologous counts between b-c and a-d, in both sexes and sides. Because, for homologous counts, high correlations signifly low fluctuating asymmetry (Jantz and Webb, 1982), we can say that the fluctuating asymmetry increases from a-d count to b-c, a-b, c-d counts.

Parameters concerning skewness and kurtosis are given in Table 3. On the basis of these two parameters (and of $\mathrm{X}^{2}$ for d.f. $=5$ ) it can be said that distributions are normal only for count a-d in both sexes while in all other cases either for parameter $g_{1}$ (skewness) or $g_{2}$ (kurtosis), either on one side or the other, there is a significant difference from zero. On not considering side, only count a-b is found to have significant $\mathrm{g}_{1}$ and $\mathrm{g}_{2}$ values. It is therefore possible to say that the a-d ridge count is due to a large number of additive genes, whose action brings to a nearly normal distribution (e.g. = stature).

The asymmetry index is higher in males than in females, but the difference is not significant, as seen in an English sample by Jantz (1975) for the total ridge count.

Finally, on comparing our results with those of subjects from Bologna (Gualdi-Russo, 1987), it is seen that Sardinians present higher values for count b-c and lower values for counts a-b and c-d, but in any case, on the average, differences go from 0.2 to 1.7 ridges.

In conclusion, from what has been reported thus far, it can be said that there are no sex differences (in agreement with Garg and Chattopadhyay, 1983), while there are side differences (with $t$ test for paired data); the variables considered are significantly and positively correlated (except for few exceptions) and tend to be no

Table 3. Skewness, kurtosis and $\mathrm{X}^{2}$.

\begin{tabular}{|c|c|c|c|c|c|c|c|}
\hline & & \multicolumn{3}{|c|}{$a-b$} & \multicolumn{3}{|c|}{ b-c } \\
\hline & & $\mathrm{g}_{1}$ & $\mathrm{~g}_{2}$ & $\mathrm{X}^{2}$ & $\mathrm{~g}_{1}$ & $\mathrm{~g}_{2}$ & $\mathrm{X}^{2}$ \\
\hline & $\mathrm{R}$ & $0.63^{* *}$ & $0.99^{* *}$ & $15.81^{* *}$ & -0.16 & -0.47 & 9.35 \\
\hline \multirow[t]{3}{*}{$\mathrm{M}$} & $\mathrm{L}$ & $0.47^{* *}$ & $1.31^{* *}$ & $16.74^{* *}$ & $-0.30^{*}$ & -0.16 & $13.48^{*}$ \\
\hline & $\mathrm{R}+\mathrm{L}$ & $0.41^{* *}$ & 0.57 & 2.28 & -0.29 & -0.32 & 5.17 \\
\hline & $\mathrm{R}$ & $0.45^{* *}$ & $0.90^{* *}$ & $19.01^{* *}$ & -0.17 & -0.11 & 8.18 \\
\hline \multirow[t]{4}{*}{$\mathrm{F}$} & $\mathrm{L}$ & $1.19^{*}+$ & $2.74^{* * *}$ & $19.69^{* *}$ & $-0.33^{*}$ & 0.24 & $13.23^{*}$ \\
\hline & $\mathrm{R}+\mathrm{L}$ & $0.91^{* *}$ & $1.87^{* *}$ & 9.78 & -0.27 & -0.09 & 6.09 \\
\hline & & & $c-d$ & & & $\mathrm{a}-\mathrm{d}$ & \\
\hline & $\mathrm{R}$ & -0.28 & $0.99^{* *}$ & $12.18^{*}$ & -0.01 & -0.57 & 6.71 \\
\hline \multirow[t]{3}{*}{ M } & $\mathrm{L}$ & -0.24 & $0.91^{* *}$ & $11.26^{*}$ & -0.19 & -0.53 & 7.32 \\
\hline & $\mathrm{R}+\mathrm{L}$ & -0.14 & 0.58 & 5.35 & -0.13 & -0.58 & 5.17 \\
\hline & $\mathrm{R}$ & $-0.38^{*}$ & 0.42 & 4.55 & -0.25 & -0.22 & 3.75 \\
\hline \multirow[t]{2}{*}{$\mathrm{F}$} & $\mathrm{L}$ & $-0.48^{* *}$ & 0.34 & 8.68 & -0.03 & -0.14 & 6.46 \\
\hline & $\mathrm{R}+\mathrm{L}$ & $-0.39^{* *}$ & 0.18 & 10.15 & -0.15 & -0.15 & 2.40 \\
\hline
\end{tabular}

$\mathrm{sg}_{1}=0.15, \mathrm{sg}_{2}=0.30, \mathrm{~N}=260, \mathrm{t}=\mathrm{g}_{1} / \mathrm{sg}_{1}$ and $\mathrm{t}=\mathrm{g}_{2} / \mathrm{sg}_{2} . \mathrm{X}^{2}$ with d.f. $=5 .{ }^{*} p \leq 0.05^{* *} p \leq 0.01$. 
normally distributed with the exceptions of the a-d ridge count in both the sexes and the sides and in the two sides together.

\section{References}

Ahuja, Y. R., Murty, J. S., Plato, C. C., \& Schwartz, J. T. (1977). Inheritance Studies of c-t and a-d Intertriradial Distances on the Palm by Means of Twin Pair Analysis. Zeitschrift fur Morphologie und Anthropologie, 68, 220-225.

Arrieta, M. I., Criado, B., Hauspie, R., Martinez, B., Lobato, N., \& Lostao, C. M. (1992). Effects of Genetic and Environmental Factors on the a-b, b-c and c-d Interdigital Ridge Counts. Hereditas, 117, 189-194. http://dx.doi.org/10.1111/j.1601-5223.1992.tb00173.x

Babu, M. S. (1983). Correlation between Ridge Counts on Different Palmar Interdigital Areas. Dermatoglyphics, 11, $28-42$.

Balgir, R. S., \& Sharma, J. C. (1986). Dermatoglyphic Studies among the Two Breeding Isolates of Guujjars of Northwestern India. American Journal of Physical Anthropology, 71, 467-476. http://dx.doi.org/10.1002/ajpa.1330710410

Bansal, I. J. S., Singhal, P., \& Kaur, R. (1984). Age Changes in Palmar Dermatoglyphics. Dermatoglyphics, 12, 1-8.

Barbensi, G. (1952). Introduzione alla biometria. Firenze: Vallecchi.

Basu, A. (1971). The a-d Ridge Count in Palmar Dermatoglyphics of Three Groups of Mysora Brahman. Human Heredity, 21, 192-197. http://dx.doi.org/10.1159/000152401

Bhasin, M. K. (1970). Group Differences among Newars of Nepal for Palmar Interdigital Areas. Human Heredity, 20, 604608. http://dx.doi.org/10.1159/000152366

Braitsch, H., \& Schwarzfischer, F. (1959). Zur Biometrie und Geographischen Verteilung der Leistenzahlen in den Interditalfeldern der Handflache. Homo, 10, 226-236.

Brehme, H., \& Hitzeroth, H. W. (1979). Hautleistenbefunde bei Bantusprechenden, Negriden Populationen der Republik Sudafrika. Teil 1. Fingerbeeren und Handflachen. Zeitschrift fur Morphologie und Anthropologie, 70, 195-217.

Brehme, H., \& Hitzeroth, H. W. (1980). Hautleistenbefunde bei Bantusprechenden Popolationen der Republik Sudafrika. Tell 2. Zehenbeeren und Fussohlen. Zeitschrift fur Morphologie und Anthropologie, 70, 310-322.

Brehme, H., \& Jantz, R. L. (1990). Palm and Sole Interdigital Ridge-Count Correlations. Zeitschrift fur Morphologie und Anthropologie, 78, 243-256.

Brehme, H., Okajima, M., \& Wittmann, W. W. (1977). Uber Quantitative Werte des Hautleisten-Systems aus Der Deutschen und Japanischen Normalbevolkerung. Mitt Anthrop Gesell, 107, 40-51.

Chai, C. K. (1971). Analysis of Palm Dermatoglyphics in Taiwan Indigenous Populations. American Journal of Physical Anthropology, 34, 369-376. http://dx.doi.org/10.1002/ajpa.1330340306

Chattopadhyay, P. K., \& Kushwaka, K. P. S. (1978). A Dermatoglyphic Approach to the Problem of Rajput Origin. Mankind Quarterly, 18, 186-201.

Cummins, H., \& Midlo, C. (1961). Finger Prints, Palms and Soles. New York: Dover Publications.

Deep Kumar, V. S., \& Ramachandraiah, T. (1991). Finger and Palmar Dermatoglyphic Study among the Narikorava. In B. M. Reddy, S. B. Roy, \& B. N. Sarkar (Eds.), Dermatoglyphic Today (pp. 343-355). Calcutta: IBRAD.

Demarchi, D. A., \& Marcellino, A. J. (1994). Dermatoglyphics among the Macaco Indians of the Gran Chaco (Argentina). Dermatoglyphics, 13, 29-34.

Demarchi, D. A., \& Marcellino, A. J. (1995). Dermatoglyphics in Pilaga Indians of the Gran Chaco (Argentina). Dermatoglyphics, 14, 11-27.

Dennis, R. H. L. (1977). A Study of Dermatoglyphic Variation in the Human Populations of the North Pennine Dales. Ph.D. Thesis, Durham: University of Durham.

Floris, G. (1993). Alcuni dati sul conteggio palmare a-d. Rendiconti Seminario Facoltà Scienze Università Cagliari, 63, 177180.

Floris, G., \& Sanciu, G. M. (1989). I conteggi intertriradiali palmari nei Sardi: Nota preliminare. Antropologia Contemporanea, 12, 51-55.

Floris, G., \& Sanna, E. (1982). The a-b Ridge Count. Dermatoglyphics, 10, 16-19.

Floris, G., \& Sanna, E. (1983). On the Absence of Triradius d on the Human Palm. Dermatoglyphics, 11, 15-18.

Floris, G., \& Sanna, E. (1987). I dermatoglifi qualitative palmari come indicatori di relazioni tra le popolazioni maschili della Sardegna. Rivista di Antropologia, 65, 235-248.

Galaktionov, O. K., Efimov, V. M., Golsova, T. V., \& Lemza, S. V. (1981). Dermatoglyphics of Nganasans and the Forest Entsy from the Taimir Peninsula. American Journal of Physical Anthropology, 55, 111-120. 
http://dx.doi.org/10.1002/ajpa.1330550115

Garg, R. K., \& Chattopadhyay, P. K. (1983). Sexual Dimorphism in Finger and Palmar Ridge Counts of the Gaur Brahmins. Dermatoglyphics, 11, 43-46.

Gill, P. S., Bhalla, V., Sunderland, E., Woolley, V., \& Chopra, S. K. R. (1982). Digital and Palmar Dermatoglyphics in the Lowland Rajputs of Punjab. Bionature, 2, 69-76.

Gualdi-Russo, E. (1987). Palmar Dermatoglyphics in a Sample of Italian Population. International Journal of Anthropology, 2, 105-116. http://dx.doi.org/10.1007/BF02442355

Gyenis, G. (1984). Dermatoglyphics of the Paloc People in Northern Hungary. Humanbiologia Budapestinensis, $15,1-106$.

Hauser, G., \& Abraham, R. (1985). Size and Shape in Dermatoglyphic Analysis of Palmar Interdigital Areas. Annals of Human Biology, 12, 53-66. http://dx.doi.org/10.1080/03014468500007561

Hitzeroth, H. W., \& Brehme, H. (1974). Befunde des Hautleistensystems einer Interstichprobe aus dem Transvaal/Republik Sudafrika. Anthropologischer Anzeiger, 34, 184-209.

Hitzeroth, H. W., Brehme, H., \& Jantz, R. L. (1986). Dermatoglyphic Findings of a Coloured Sample from the Transvaal, Republic of South Africa. Zeitschrift fur Morphologiue und Anthropologie, 76, 219-238.

Jaeger, U. (1971). Untersuchungen uber das Hautleistensystem einer normalen und geisteskranken Probandengruppe aus Thuringen. Ph.D. Thesis.

Jantz, R. L. (1975). Population Variation in Asymmetry and Diversity from Finger to Finger for Digital Ridge Counts. American Journal of Physical Anthropology, 42, 215-223. http://dx.doi.org/10.1002/ajpa.1330420207

Jantz, R. L. (1977). Sex and Race Differences in Finger Ridge-Count Correlations. American Journal of Physical Anthropology, 46, 171-176. http://dx.doi.org/10.1002/ajpa.1330460122

Jantz, R. L., \& Webb, R. S. (1982). Interpopulation Variation in Fluctuating Asymmetry of the Palmar A-B Ridge-Count. American Journal of Physical Anthropology, 57, 253-259. http://dx.doi.org/10.1002/ajpa.1330570303

Jantz, R. L., Brehme, H., \& Eriksson, A. W. (1992). Dermatoglyphic Variation among Finno-Ugric Speaking Populations: Methodological Alternatives. American Journal of Physical Anthropology, 89, 1-10. http://dx.doi.org/10.1002/ajpa.1330890102

Jantz, R. L., Brehme, H., \& Hunt, D. R. (1988). Covariation among Palmar Interdigital Ridge-Counts. Internationl Journal of Anthropology, 3, 339-344.

Kamali, M. S. (1982). Dermatoglyphics of Iranians of African Descent. Dermatoglyphics, 10, 4-15.

Karmakar, B., \& Malhotra, K. C. (1985). Inter-Variable Relationships Based on Quantitative Dermatoglyphic Traits in a Pooled Series of the Dhangars of Maharashtra. Dermatoglyphics, 13, 25-34.

Karmakar, B., Vasu, T. S., Malhotra, K. C., \& Bhanu, B. V. (1996). Variation in Palmar Interdigital Ridge-Counts among the 20 Dhangar Castes of Maharashtra, India. Anthropologischer Anzeiger, 54, $239-253$.

Knussmann, R. (1971). Zur frage nach Beziehung zwischen Diabetes mellitus und Hautleistensystem. In W. Hirsch (Ed.), Hautleisten und Krankheiten II (pp. 159-187). Berlin: Grosse Verlag.

Lodeiro Ainsua, R., Garcia Nimo, M. L., \& Farna Farina, J. (1985). Valores quantitative de las distancias entre los triradios palmares a, b, c y d en una maestra de la poblacione galleca. Actas IV Congreso Espanol de Antropologia Biologica II, 767-776.

Máté, M. (1975). The Ridge-Counts of the Interdigital a-b, b-c and c-d Areas in a Normal Sample and in Cerebrally Damages Patients of Thuringia, G.D.R. (East Germany). American Journal of Physical Anthropology, 42, 233-236. http://dx.doi.org/10.1002/ajpa.1330420210

Milicic, J., \& Rudan, P. (1991). Population Structure of the Adriatic Islands: Dermatoglyphic Analyses. In B. M. Reddy, S. B. Roy, \& B. N. Sarkar (Eds.), Dermatoglyphic Today (pp. 256-269). Calcutta: IBRAD.

Milicic, J., \& Vidovic, M. (2005). Latent Structure of Dermatoglyphics in the Population of Selska Valley. Homo, 56, 161172. http://dx.doi.org/10.1016/j.jchb.2004.12.002

Narahari, S., Malati, K. S. K., \& Dev, K. R. S. S. (2008). The Khond: A Dermatoglyphic Study. Anthropologist, 10, $207-$ 210.

Pons, J. (1982). Racial Aspects of the a-b Ridge Count on the Human Palm. Anthropologischer Anzeiger, 40, $245-251$.

Reddy, B. M., Demarchi, D. A., Bharati, S., Kumar, V., \& Crawford, M. H. (2004). Patterns of Ethnic, Linguistic, and Geographic Heterogeneity of Palmar Interdigital Ridge Counts in the Indian Subcontinent. Human Biology, 76, 211-228. http://dx.doi.org/10.1353/hub.2004.0037

Reichmann, A. (1978). Dermatoglyphics among the Toba Indians of Argentina. In J. Mavalwala (Ed.), Dermatoglyphics. An International Perspective (pp. 131-144). The Hague: De Gruyter Mouton.

http://dx.doi.org/10.1515/9783110800005.131

Rosa, P. J. (1983). Descriptive Report on a Dermatoglyphic Survey of 6235 School-Children from Kenya. Ph.D. Thesis, 
Durham: University of Durham.

Tornjova-Randelova, S., Borissova, P., \& Peskova-Topalova, D. (2008). Quantitative Characterization of Finger and Palm Dermatoglyphics in Bulgarians. Anthropologischer Anzeiger, 66, 295-315.

Weninger, M. (1978). Critical Remarks on Some Methodological Procedures in the Field of Dermatoglyphics. In: J. Mavalwala (Ed.), Dermatoglyphics. An International Perspective (pp. 11-17). The Hague: De Gruyter Mouton.

http://dx.doi.org/10.1515/9783110800005.11 